\title{
Morphophysiology of the Epididymis of the African Sideneck Turtle (Pelusios castaneus): Histological, Microstereological and Ultrastructural Approach
}

\author{
Olukole, S. G and Oke, B. O. \\ Department of Veterinary Anatomy, Faculty of Veterinary Medicine, University of Ibadan, Ibadan, Nigeria. \\ *Author for Correspondence: sg.olukole@mail.ui.edu.ng; +2348033574752
}

\begin{abstract}
Article History
Received: $21^{\text {st }}$ Feb, 2020

Revised: $14^{\text {th }}$ March, 2020

Accepted: $15^{\text {th }}$ March, 2020

Published: $31^{\text {st }}$ March, 2020
\end{abstract}

\begin{abstract}
This study was carried out to describe the morphophysiology of the epididymis of the adult African sideneck turtle using histological, microstereological and ultrastructural methods. The epididymal duct lies within a relatively thin sheath of connective tissue, and is lined by pseudostratified columnar epithelium. Unlike luminal diameter and stereocilial height, epithelial height, as well as the population of principal cells, decreased from the proximal to posterior segment. The clear cells of the turtle epididymis are limited to the posterior segment of the duct. Basal and apical cells as well as intraepithelial lymphocytes are all distributed across the three segments of the epididymis while macrophage-like cells are absent throughout the length of the duct epithelium. The structure of the African sideneck turtle epididymis demonstrates, as in most mammals and few reptiles studied to date, obvious regional differentiation of the duct epithelium with evidences of secretory and endocytotic abilities as demonstrated by the contents of highly developed endoplasmic reticulum and secretory blebs in the principal and basal cells as well as clear cells, believed to be concerned with endocytosis. The outcome of the study is expected to be useful in the comparative structural and functional anatomy of turtle epididymis.
\end{abstract}

Keywords: African sideneck turtle; epididymis; ultrastructure; microstereology; principal cell.

\section{Introduction}

Turtles of the genus Pelusios belong to the family Pelomedusidae which are characterised by their inability to fully withdraw their head into their shell but instead, draw it to the side and fold it beneath the upper edge of the shell. For this reason, they are called sideneck turtles (Broadley and Boycott, 2009).

The African sideneck turtle (Pelusios castaneus) is a freshwater turtle, widely distributed in West Africa, from Guinea and Senegal to northwestern Angola (Kirkpatrick, 1995). It is small to medium in size, with relatively extensive plastron that may have a hinge present between the pectoral and abdominal scutes (Olukole and Oke, 2014).

The epididymal duct is a channel that transports, concentrates and stores spermatozoa which, on leaving the testis, are immotile, immature and unable to fertilize an oocyte (Yanagimachi et al., 1985; Flesch and Gadella, 2000). Under androgen control, the epididymal epithelium secretes proteins into the intra-luminal compartment that assist in the maturation of spermatozoa (Hermo et al., 1988, Hermo et al., 1998; Sullivan, 2004). This luminal compartment stores the spermatozoa until ejaculation and specifically prepares the sperm for fertilization by providing the essentials in terms of temperature, oxygen tension, $\mathrm{pH}$ and available energy substrate (Dacheux et al., 2005).

While studies abound on the structure, function, and regulation of the duct of the epididymis of mammals and birds (Oke et al., 1987, 1989; Gist et al., 2001; Massanyi et al., 2003; Aire, 2007; Rheubert et al., 2010a), there is limited information on the morphology of the epididymis of reptiles (Sever, 2009, Rheubert et al., 2010b; Sever et al., 2013). Reports on the gross anatomy of turtles have been documented by Wyneken (2001) as well as Kellner and Schwanke (2001). However, there is scarcity of information on the histology and ultrastructure of turtle epididymis. In addition to providing a better understanding of the functions of the epididymis, the histological and ultrastructural details of the epididymis of the African sideneck turtle would be useful in the comparative cytology of turtles and reptiles.

Preliminary studies on the gross anatomy of the epididymis of this turtle described proximal, middle and posterior segments attached to the lateral aspect of the caudal border of the testis and extending caudally to about $2-3 \mathrm{~cm}$ before transiting into the ductus deferens (Olukole et al., 2014a). To the best of our knowledge, the current study, being the first of this nature performed in any freshwater turtle species, aims 
to describe the structure of the epididymis of the African sideneck turtle on the basis of the aforementioned proximal, middle and posterior segments using histological, microstereological and ultrastructural methods.

\section{Materials and Methods \\ Experimental Animals}

Twelve adult male African sideneck turtles (Pelusios castaneus) with an average bodyweight of $0.68 \mathrm{~kg}$, were sampled in August, a period of peak spermiogenesis (Olukole et al., 2014b). The turtles were collected from river drainages in Ibadan, Nigeria. Carapacial and plastral characteristics were used in the determination of adulthood in the turtles (Kirkpatrick,1995). The turtles were anaesthetized by intramuscular injection of ketamine- $\mathrm{HCl}(25 \mathrm{mg} / \mathrm{kg}$ bodyweight) and sacrificed by cervical decapitation. The epididymis was removed after separating the plastron from the carapace and grossly divided into its proximal, middle and posterior segments as earlier described (Olukole et al., 2014a). All procedures were carried out according to the guidelines for the care and use of experimental animals, National Institute of Health (NIH), USA.

\section{Ethical Statement}

The study was approved by the University of Ibadan Animal Care and Use Research Ethics Committee (UIACUREC: 12/13/05).

\section{Light Microscopy and Microstereology}

Epididymal samples from each segment were fixed in neutral buffered formalin prior to paraffin techniques, sectioned (2-4 $\mu \mathrm{m}$ thick) and stained with Haematoxylin and Eosin (H\&E), as well as Periodic Acid Schiff, PAS (Rao and Shaad, 1985). The slides were then studied under a light microscope (Olympus BX63 with a DP72 camera). Quantitative histomorphometric measurements of the three segments of the epididymis were taken from the H\&E- stained sections, using a stereological module of computer-assisted digital image analyser (CellSens ${ }^{\circledR}$ dimension software version 1.6) attached to a computer.

\section{Transmission Electron Microscopy}

Tissues from the three segments of the epididymis were fixed in glutaraldehyde in $0.1 \mathrm{M}$ sodium cacodylate buffer $(\mathrm{pH} 7.2)$ for 4 hours at $4{ }^{0} \mathrm{C}$. The samples were processed as reported by Olukole et al. (2018). Briefly, samples were thoroughly washed in the same buffer, post-fixed in $1 \%$ osmium tetroxide, and subsequently dehydrated in graded series of ethanol. Thereafter, they were then cleared with propylene oxide, infiltrated with a 1:1 solution of propylene oxide:epoxy resin, 1:2 solution of propylene oxide:epoxy resin, and then placed in 100\% epoxy resin for 36 hours under vacuum. They were thereafter embedded in fresh epoxy resin and cured at $60^{\circ} \mathrm{C}$ for 48 hours. Semi-thin sections were stained with toluidine blue and observed under the light microscope (Olympus BX63 with a DP72 camera). Ultra-thin sections $(70-80 \mathrm{~nm})$ were cut with a diamond knife on an ultramicrotome (Ultracut- Reichert, Austria), and then double-stained with uranyl acetate and lead acetate. The copper grids were examined under a transmission electron microscope (Philips CM 10 TEM) operating at $80 \mathrm{kv}$. Representative micrographs of different segments of the epididymis were taken using a Gatan 785 Erlangshen digital camera (GatanInc, Warrendale, PA). Analysis and assembling of composite micrographs were carried out using Adobe Photoshop CS5 (Adobe Systems, San Jose, CA).

\section{Results}

\section{Histological and Ultrastructural Observations}

In all the three segments, the ductus epididymis lies within a relatively thin sheath of connective tissue and is lined by a pseudostratified columnar epithelium. The ductal diameter, luminal diameter and epithelial height varied from proximal to its posterior segment (Table 1), with the epithelial height being highest at the proximal segment and lowest at the posterior segment. However, luminal diameter was highest at the posterior segment and lowest at the proximal segment.

Table 1: Microstereology of the Epididymis of $P$. castaneus $(\mathrm{n}=12)$.

\begin{tabular}{llll}
\hline \multirow{2}{*}{\multicolumn{1}{c}{ Parameter }} & \multicolumn{3}{c}{ Epididymal Segments } \\
\cline { 2 - 4 } & Proximal & Middle & Posterior \\
\hline Ductal Diameter $(\boldsymbol{\mu m})$ & $521 \pm 30.6^{\mathrm{a}}$ & $548 \pm 42.7^{\mathrm{a}}$ & $643 \pm 65.2^{\mathrm{b}}$ \\
Luminal Diameter $(\boldsymbol{\mu m})$ & $386 \pm 22.6^{\mathrm{a}}$ & $496 \pm 36.7^{\mathrm{b}}$ & $560 \pm 50.5^{\mathrm{c}}$ \\
Epithelial Height $(\boldsymbol{\mu m})$ & $84.2 \pm 8.1^{\mathrm{a}}$ & $62.5 \pm 7.5^{\mathrm{b}}$ & $40.3 \pm 5.4^{\mathrm{c}}$ \\
Stereocilia height $(\boldsymbol{\mu m})^{\mathrm{b}}$ & $7.2 \pm 0.4^{\mathrm{a}}$ & $11.6 \pm 1.2^{\mathrm{b}}$ & $18.5 \pm 1.4^{\mathrm{c}}$ \\
\hline
\end{tabular}

$\overline{a, b, c}$ Means with different superscript within rows differ significantly $(\mathrm{P}<0.05)$.

\section{Proximal segment}

The epithelial height, ductal and luminal diameters of the proximal segment of the epididymis of the African sideneck turtle are shown in Table 1. This segment has the highest epithelial height as well as the lowest luminal diameter when compared to the other two segments. The cell types in the epithelium of the proximal segment are the principal and basal cells, very few apical cells, and intra-epithelial

lymphocytes (Figs. 1A, 2A and 3A).
The lamina propria consists of loose connective tissue with smooth muscles (Fig. 1A). The principal cells in the proximal segment form about $80 \%$ of the total epithelial cell population. They are long cylindrical, columnar cells, ranging from $50-60 \mu \mathrm{m}$ in length, extending from the basement membrane to the adluminal surface with their stereocilia projecting as far as $7.2 \pm 0.4 \mu \mathrm{m}$ into the duct lumen (Table 1, Fig. 1A). Their vesicular nuclei possess one or two nucleoli The supranuclear cytoplasm of the principal cells in this region displays numerous mitochondria, rough endoplasmic 
reticula, free ribosomes and tight junctions with a few intercellular vacuoles (Fig. 4A). The few apical cells encountered in this segment have a characteristic apically located spherical nucleus but do not contact the basement membrane.

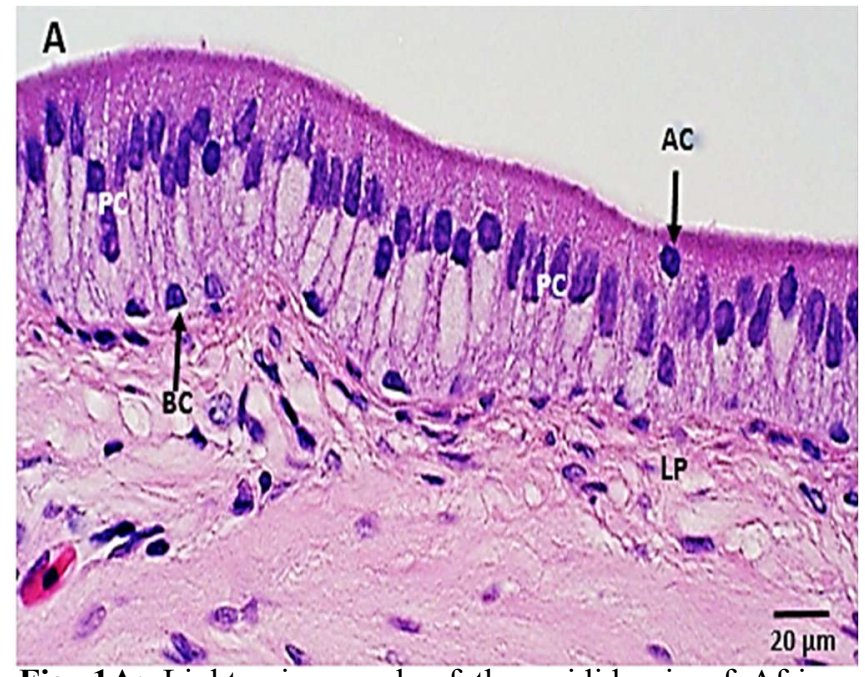

Fig. 1A: Light micrograph of the epididymis of African sideneck turtle (Proximal segment), PC: principal cell; BC: basal cell; AC: apical cell; LP: lamina propria (H\&E).

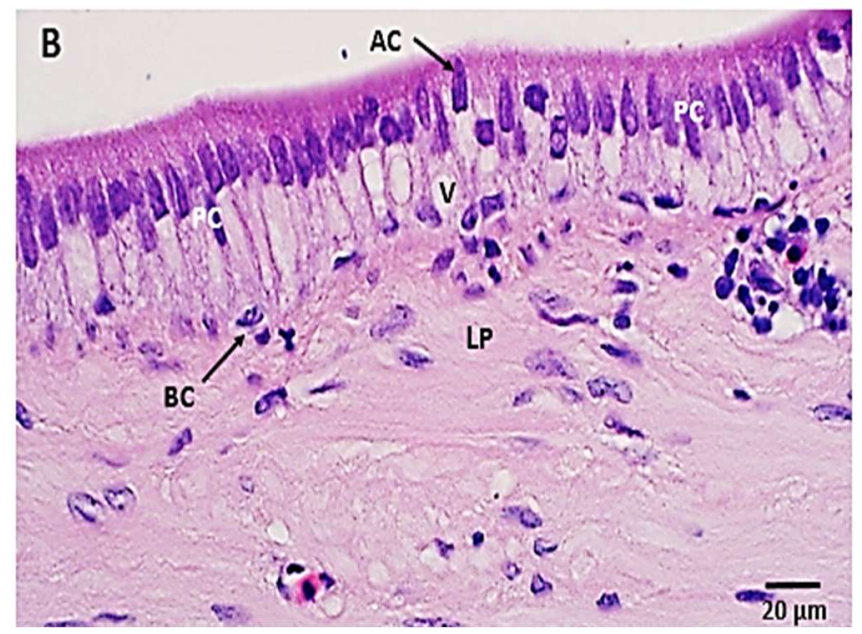

Fig. 1B: Light micrograph of the epididymis of African sideneck turtle (Middle segment), PC: principal cell; BC: basal cell; AC: apical cell; LP: lamina propria; V: vacuole (H\&E).

Apical cells of this segment bear cellular debris, numerous mitochondria, intercellular vacuoles as well as microvilla (Fig. 4A). Basal cells were found resting on the basement membrane without reaching the ad-luminal surface (Figs. 1A, $2 \mathrm{~A}$ and $3 \mathrm{~A})$. They possess pear-shaped nucleus and thin attenuated processes that extend along the basement membrane from their main hemispherical cell body (Figs. 3A and $5 \mathrm{~A})$. The prominent organelles found within the basal cells were abundance of mitochondria, ribosomes and rough endoplasmic reticula (Fig. 5A). Intra-epithelial lymphocytes were found in-between the principal cells in this segment, having round to spherical nuclei of about $5 \mu \mathrm{m}$ in diameter (Figs. 3A and 6A). The cytoplasm of the intra-epithelial lymphocytes of this segment is composed of mitochondria, numerous free ribosomes as well as rough endoplasmic reticula (Fig. 6A).

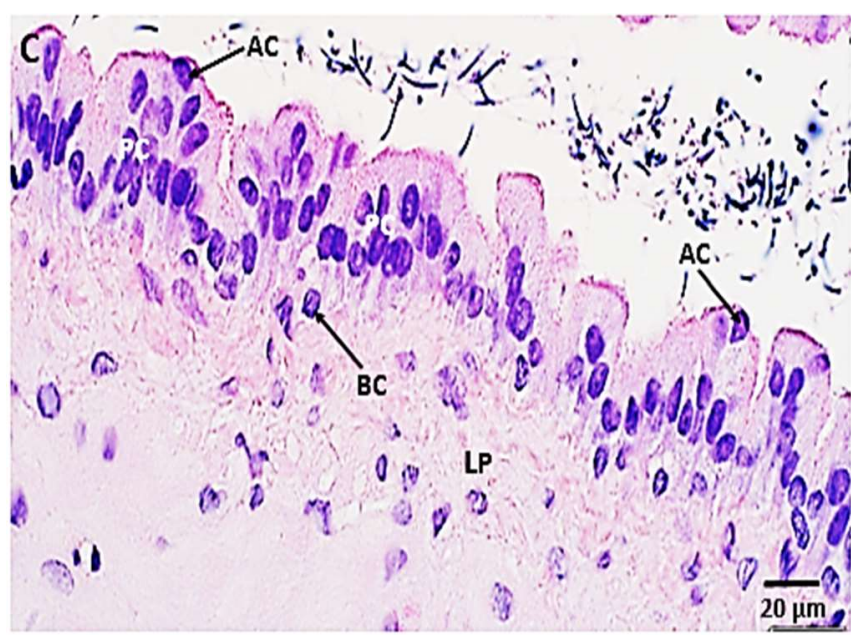

Fig. 1C: Light micrograph of the epididymis of African sideneck turtle (Posterior segment) PC: principal cell BC: basal cell; AC: apical cell; LP: lamina propria; V: vacuole; $\mathrm{SC}$ : stereocilia (PAS).

The supranuclear cytoplasm of the principal cells in this region displays numerous mitochondria, rough endoplasmic reticula, free ribosomes and tight junctions with a few intercellular vacuoles (Fig. 4A). The few apical cells encountered in this segment have a characteristic apically located spherical nucleus but do not contact the basement membrane. Apical cells of this segment bear cellular debris, numerous mitochondria, intercellular vacuoles as well as microvilla (Fig. 4A). Basal cells were found resting on the basement membrane without reaching the ad-luminal surface (Figs. 1A, 2A and 3A). They possess pear-shaped nucleus and thin attenuated processes that extend along the basement membrane from their main hemispherical cell body (Figs. 3A and $5 \mathrm{~A})$. The prominent organelles found within the basal cells were abundance of mitochondria, ribosomes and rough endoplasmic reticula (Fig. 5A). Intra-epithelial lymphocytes were found in-between the principal cells in this segment, having round to spherical nuclei of about $5 \mu \mathrm{m}$ in diameter (Figs. 3A and 6A).

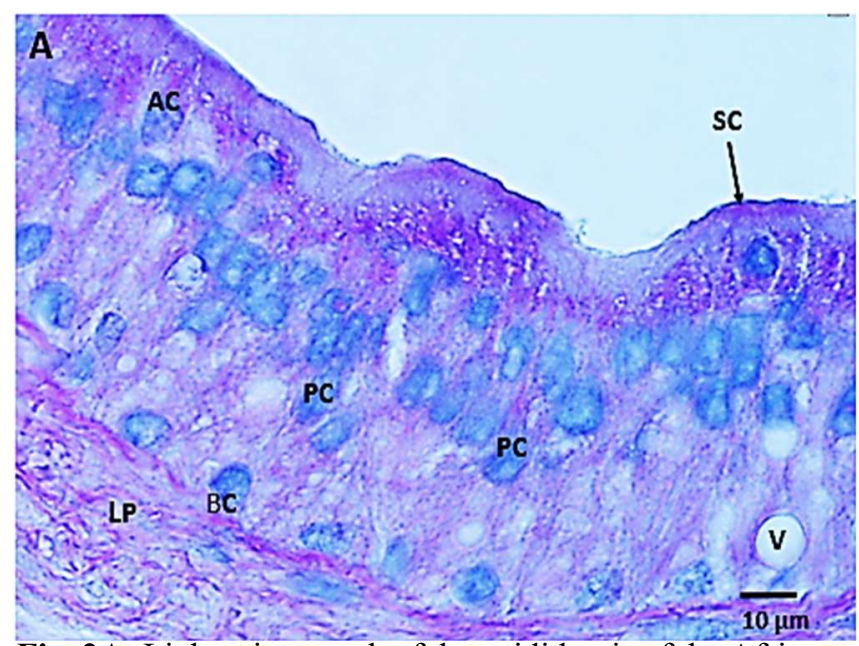

Fig. 2A: Light micrograph of the epididymis of the African sideneck turtle (Proximal segment). PC: principal cell; BC: basal cell; AC: apical cell; LP: lamina propria; V: vacuole; SC: stereocilia (PAS). 


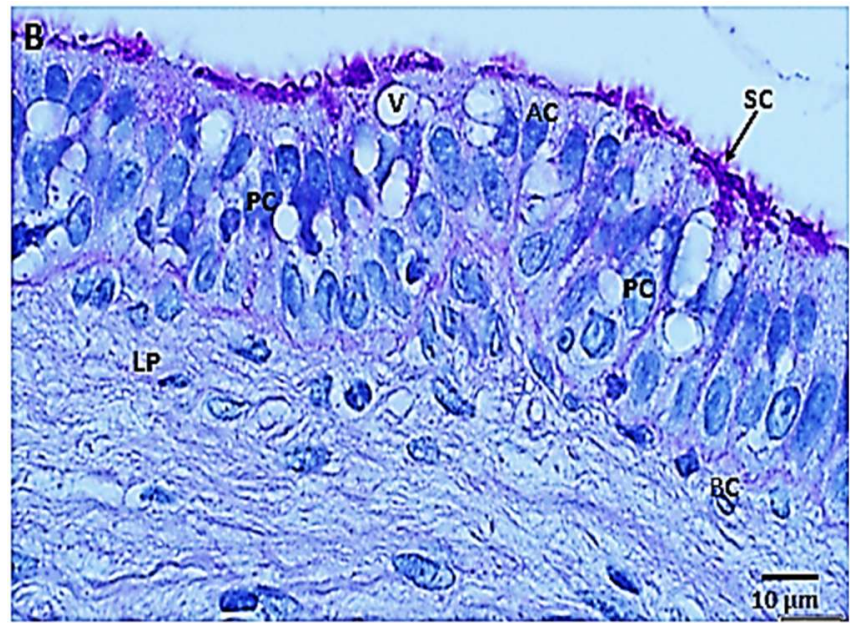

Fig. 2B: Light micrograph of the epididymis of the African sideneck turtle (Middle segment), PC: principal cell; BC: basal cell; AC: apical cell; LP: lamina propria; V: vacuole; SC: sterocilia (PAS).

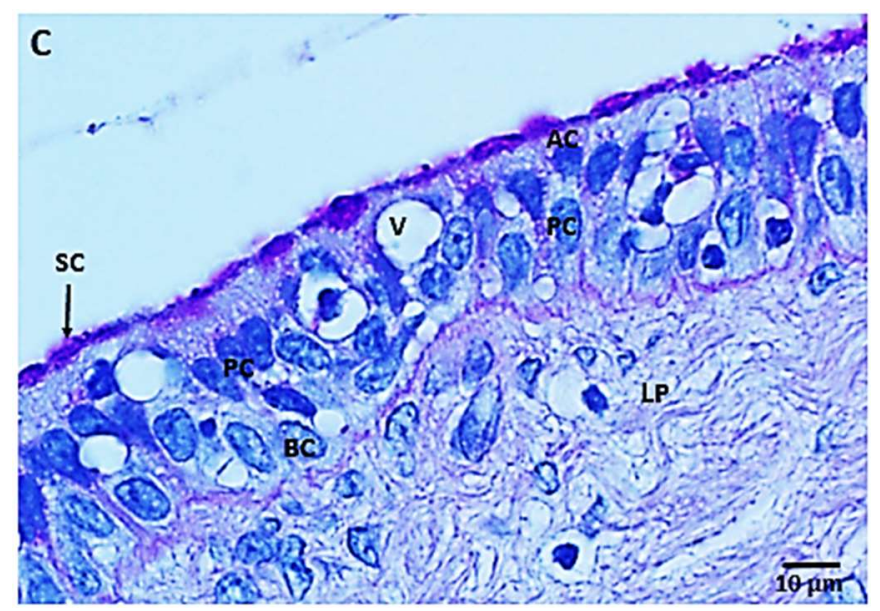

Fig. 2C: Light micrograph of the epididymis of the African sideneck turtle (Posterior segment), PC: principal cell; BC: basal cell; AC: apical cell; LP: lamina propria; V: vacuole; $\mathrm{SC}$ stereocilia. (PAS).

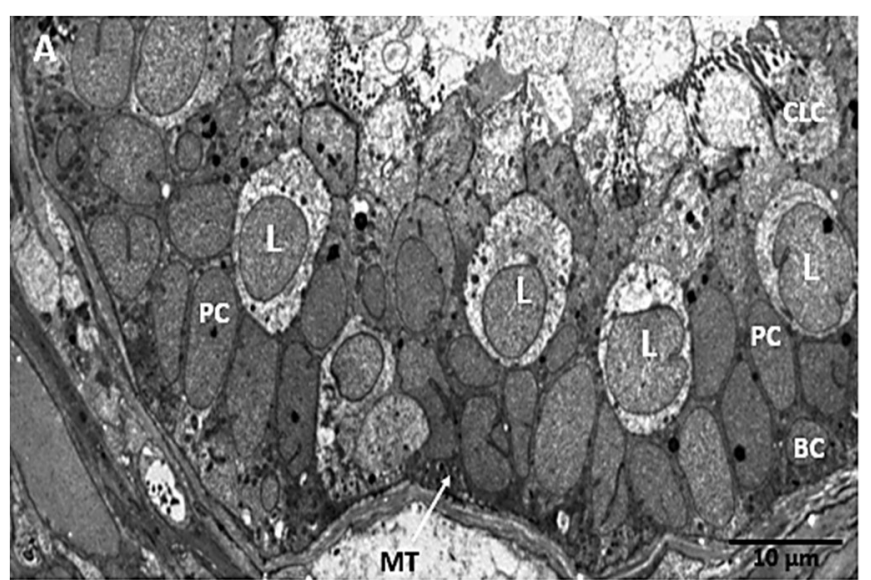

Fig. 3A: Transmission Electron Micrograph of the epididymis of the African sideneck turtle showing (Proximal segment), CLC: ciliated cell; PC: principal cell; BC: basal cell; L: lymphocyte; MT: mitochondria

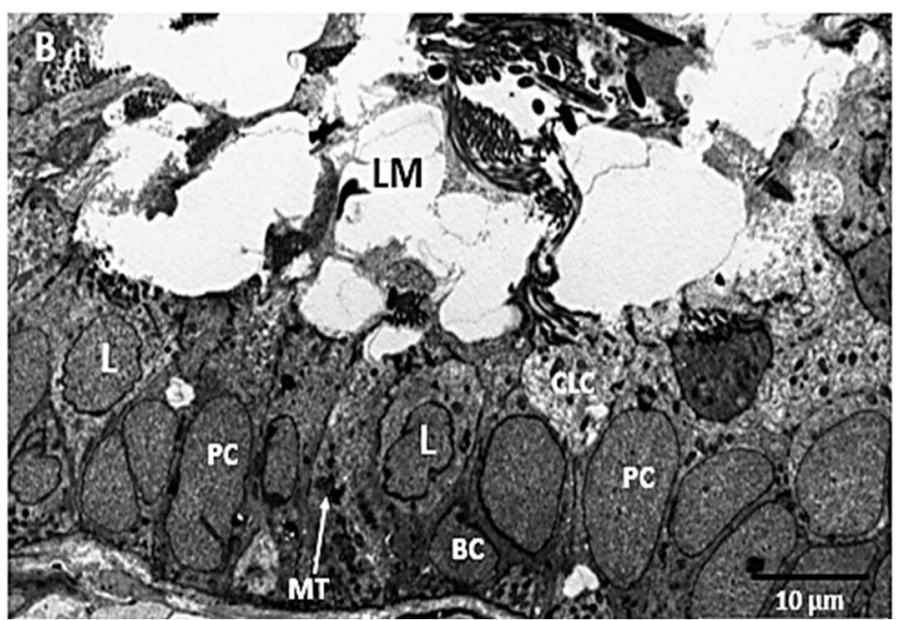

Fig. 3B: Transmission Electron Micrograph of the epididymis of the African sideneck turtle showing (Middle segment), CLC: ciliated cell; PC: principal cell; BC: basal cell; L: lymphocyte; LM: lumen; MT: mitochondria

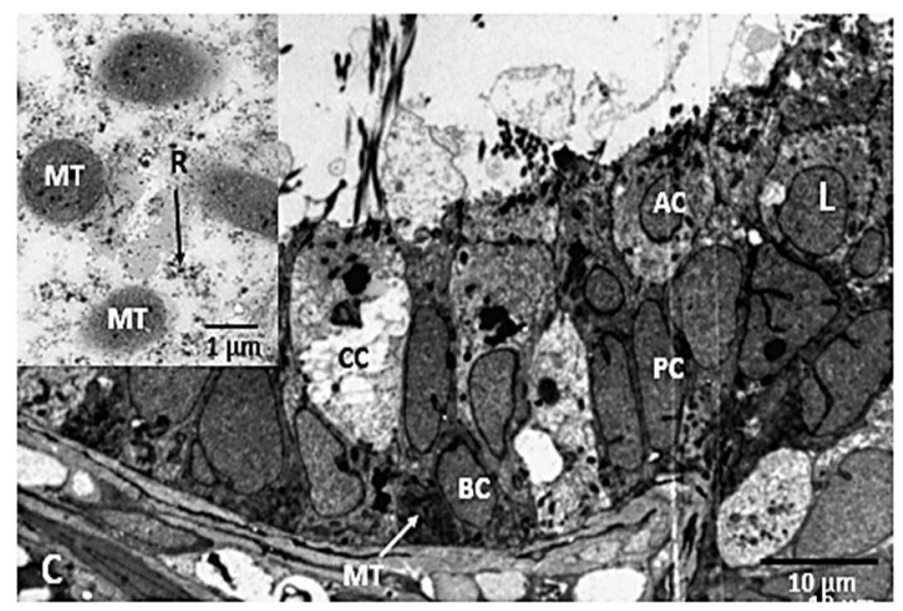

Fig. 3C: Transmission Electron Micrograph of the epididymis of the African sideneck turtle showing (Posterior segment), AC: Apical cell; CC: clear cell; PC: principal cell; BC: basal cell; L: lymphocyte; MT: mitochondria. Inset: Cytoplasm of clear cell. MT: mitochondria; R: free ribosomes

The cytoplasm of the intra-epithelial lymphocytes of this segment is composed of mitochondria, numerous free ribosomes as well as rough endoplasmic reticula (Fig. 6A).

\section{Middle segment}

The epithelial height, ductal and luminal diameters of the middle segment of the epididymis of the African sideneck turtle are shown in Table 1. The epithelium is shorter in this segment compared to that of the proximal segment. Stereocilia projecting from the apical portions of the epithelium into the lumen of the duct are longer than those of the proximal segment (Table 1). The typical cell types in the epithelium of the middle segment are the principal and basal cells, very few apical cells and intra-epithelial lymphocytes (Figs. 1B, 2B and 3B). The lamina propria consists of loose connective tissue with fewer smooth muscle cells than those of the proximal segment (Figs. 1B and 2B). Principal cells in the middle segment form about $75 \%$ of the total epithelial cell population. They are also long cylindrical, columnar cells, ranging from $30-45 \mu \mathrm{m}$ in length but with fewer nuclei compared to those 
of the proximal segment. The Principal cells of this segment have spherical to vesicular nuclei with one or two nucleoli (Figs. 1B, 2B and 3B). The supra-nuclear cytoplasm of this segment, displays more mitochondria, rough endoplasmic reticula and free ribosomes compared to the proximal segment (Fig. 4B). This segment bears apical secretory cells that contain numerous mitochondria (Fig. 4B). Basal cells in this segment did not differ from those of the proximal segment in terms of their position and structure. The prominent organelles found within the basal cells were abundance of mitochondria, ribosomes and rough endoplasmic reticula (Fig. 5B).

Also, intra-epithelial lymphocytes were found in-between the principal cells in this segment. The dimensions and structure of these lymphocytes did not differ from those encountered at the proximal segment (Figs. 3B and 6B). The cytoplasm of the intra-epithelial lymphocytes of this segment, like that of the proximal segment, is composed of mitochondria, numerous free ribosomes as well as rough endoplasmic reticula (Fig. 6 B).

\section{Posterior segment}

The epithelial height, ductal and luminal diameters of the posterior segment of the epididymis of the African sideneck turtle are shown in Table 1. The epididymal epithelium in this segment is the shortest of the three segments but has the widest lumen (Table 1). Stereocilia projecting from the epithelial surface of this segment was the tallest of the three segments, being significantly different from those of the proximal and middle segments (Table 1). The cell types constituting the epithelium of the posterior segment are the principal, apical and basal cells, as well as intra-epithelial lymphocytes and clear cells, the latter being resident only in the posterior segment (Figs. 1C, 2C and 3C). The spermatozoa content of the duct in this segment is compact (Fig. 1C). The principal cells in this segment are shorter than those of both proximal and middle segments, constituting about $65 \%$ of the total epithelial cell population. The structures of the principal, basal and intra-epithelial lymphocytes of this segment did not differ from those of the proximal and middle segments. Apical cells were more frequently encountered in this segment than the other segments (Fig. 1C). The main feature of this segment which clearly distinguishes it from the other segments is the clear cell (Fig. 3C). It is a tall "flask-shaped" cell extending from the basement membrane to the duct lumen (Fig. 3C). The cytoplasm of the clear cell is composed of numerous mitochondria and free ribosomes (Fig. 3C).

Basal cells in this segment did not differ from those of the proximal and middle segments in terms of their position and structure (Figs. 1C, 2C and 3C). The prominent organelles found within the basal cells were abundance of mitochondria, ribosomes and rough endoplasmic reticula (Fig. 5C). However, this segment had more mitochondria, ribosomes and rough endoplasmic reticula than the two segments.

Also, like in the other two segments, intra-epithelial lymphocytes were found in-between the principal cells in the posterior segment. The dimensions and structure of these lymphocytes did not differ from those encountered at the proximal and middle segments (Figs. 3C and 6C). The cytoplasm of the intra-epithelial lymphocytes of the posterior segment, like those of the proximal and middle segments, is composed of mitochondria, numerous free ribosomes as well as rough endoplasmic reticula (Fig. 6C).
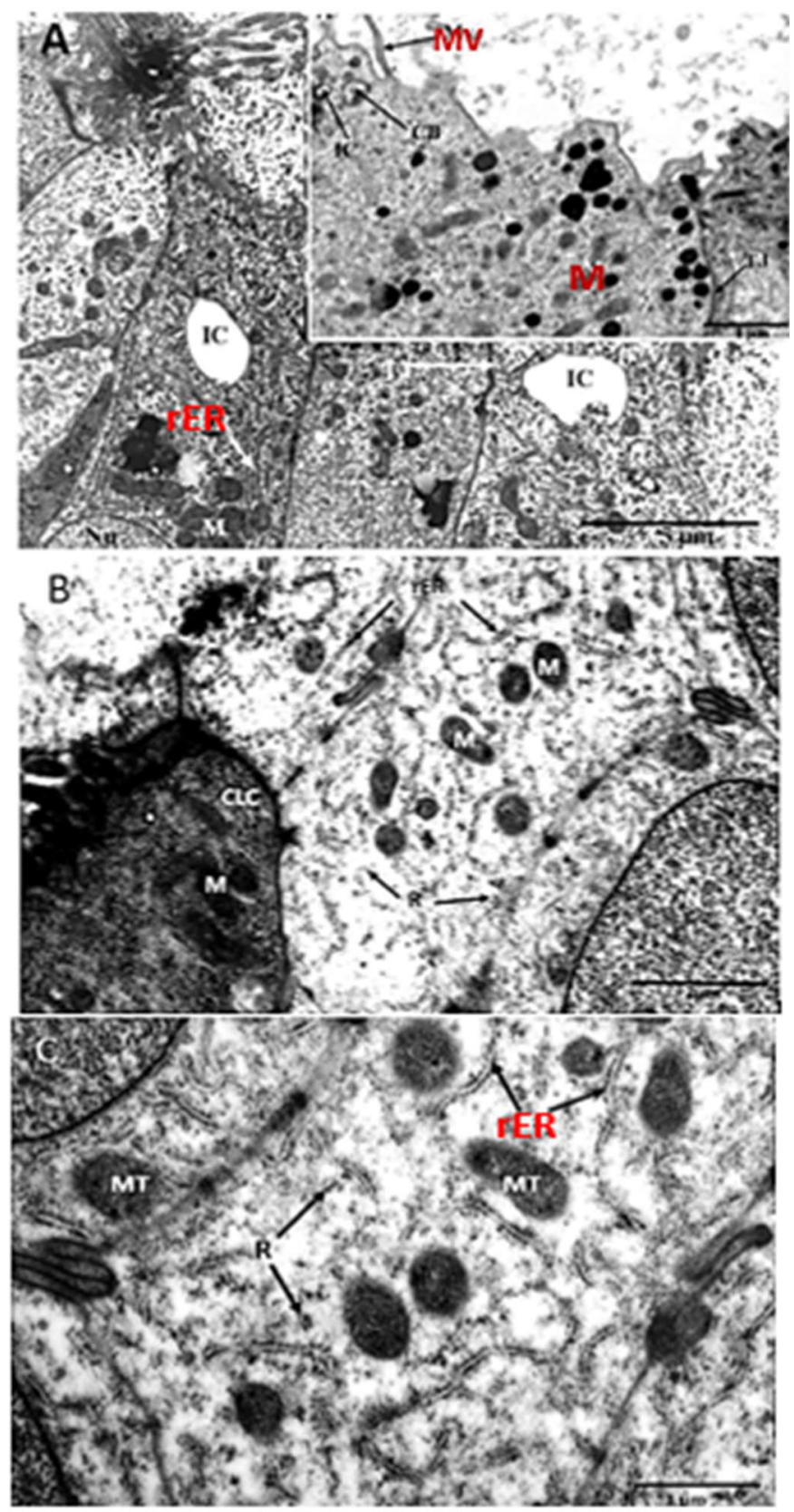

Fig. 4: Transmission Electron Micrograph of the supranuclear region of the principal cell of the epididymis in the African sideneck turtle. (A) Proximal segment, IC: intercellular vacuoles; $\mathrm{M}$ : mitochondria; $\mathrm{Nu}$ : nucleus of the principal cell; rER: rough endoplasmic reticulum; TJ: tight junction. Inset: CB: cellular debris; CF: collagen fibres; IC: Intercellular vacuoles; $\mathrm{M}$ : mitochondria; $\mathrm{MV}$ : microvillus; TJ: Tight junction. (B) Middle segment, M: mitochondria; Nu: nucleus of the principal cell; rER: rough endoplasmic reticulum; R: free ribosomes; CLC: ciliated cell. (C) Posterior segment, MT: mitochondria; rER: rough endoplasmic reticulum; R: free ribosomes. 


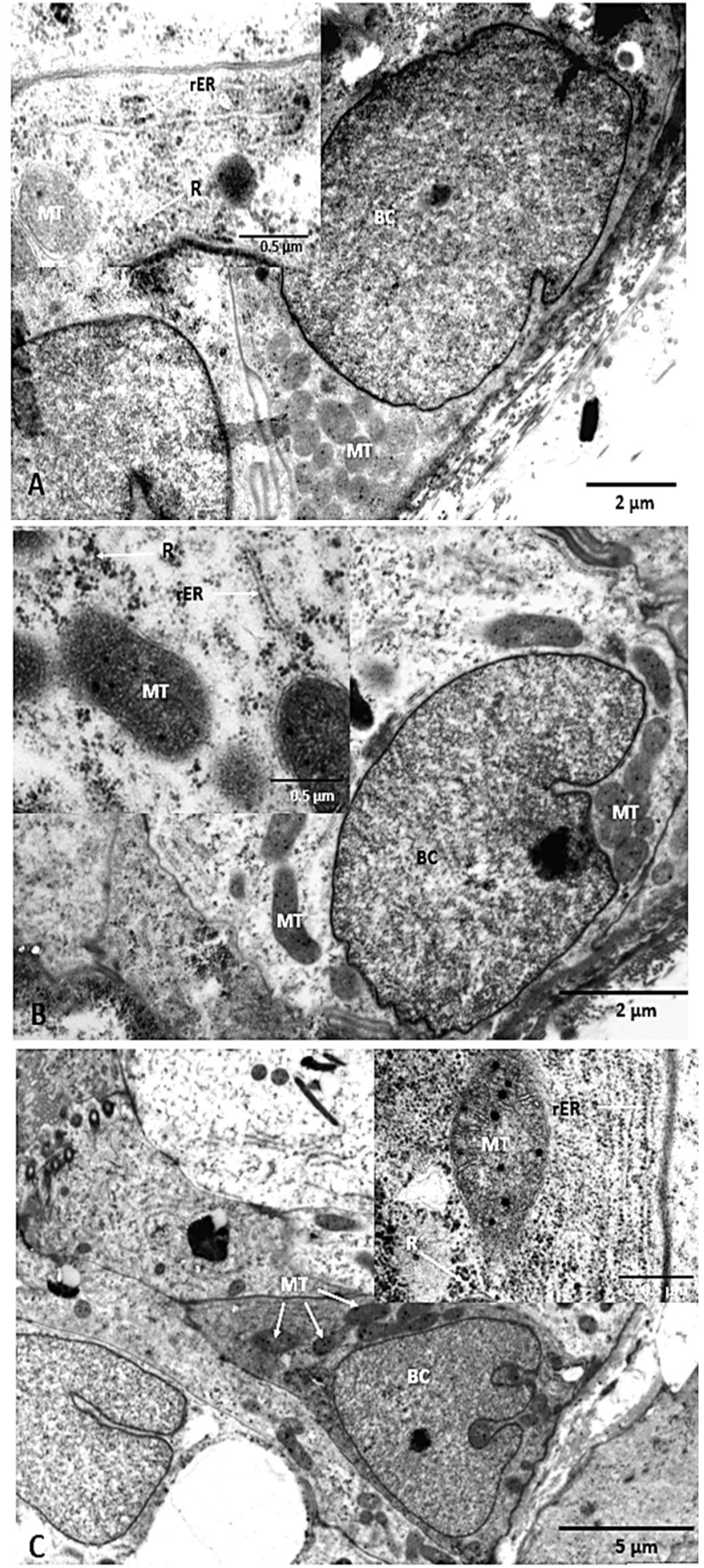

Fig. 5: Transmission Electron Micrograph of the basal cell of the epididymis of the African sideneck turtle (A) Proximal segment, BC: basal cell nucleus; MT: mitochondria. Inset: Cytoplasm of basal cell. MT: mitochondria; R: free ribosomes; rER: rough endoplasmic reticula. (B) Middle segment, BC: basal cell; MT: mitochondria. Inset: Cytoplasm of basal cell. MT: mitochondria; R: free ribosomes; rER: rough endoplasmic reticula. (C) Posterior segment, BC: basal cell nucleus; MT: mitochondria. Inset: Cytoplasm of basal cell. MT: mitochondria; R: free ribosomes; rER: rough endoplasmic reticula.

\section{Discussion}

The epididymis of the African sideneck turtle differs from that of mammals in that it does not have the conventional head, body and tail regions as reported (Oke et al., 1987; Setchell et al., 1993, Olukole and Obayemi, 2010) in mammals. This finding is in conformity with earlier reports on the male reproductive organs of freshwater turtles (Kellner and Schwanke, 2001; Wyneken, 2001). In place of this is the gross sub-division of the duct into proximal, middle and posterior segments attached to the lateral aspect of the caudal border of the testis (Olukole et al., 2014a). Nevertheless, the morphometric relationships found in this study for the luminal diameter, epithelial height and epithelial ductal diameter across the proximal, middle and posterior segments of the epididymis, all follow similar patterns as in the caput, corpus and cauda epididymides of mammals in that the proximal segment had the highest epithelial height while the posterior segment had the widest lumen (Oke et al., 1987; Massanyi et al., 2003; Olukole et al., 2009; Olukole and Obayemi, 2010).

The epithelial type observed across the segments of the epididymis confirms the reports of Wyneken (2001) on reptilian epididymis. The pseudostratified columnar ciliated epithelium of the epididymis tallies with the reports on the epididymis of the snake, lizard, turtle, crocodile, birds and mammals (Djakiew and Jones, 1982; Kellner and Schwanke, 2001; Holmes and Gist, 2004; Aire, 2007; Akbarsha et al., 2007; Sever, 2009).

Across the segments investigated in this study, the principal cell is the most abundant cell type encountered and decreased in population from the proximal to posterior segments of the epididymis. Mammalian studies of the epididymis have established that principal cells constitute approximately $80 \%$ of the total epithelial cell population in the initial segment and that the number of principal cells gradually decreases to $65 \%$ of the total epithelial cell population in the cauda epididymis (Robaire and Hermo, 1988). It has been reported that principal cells are responsible for the bulk of the proteins that are secreted into the lumen and are directly involved in the control of luminal protein concentrations as evidenced by the blebs of cytoplasm emanating from the apical cell surface (Robaire et al., 2006; Cornwall, 2009). Also, the rough endoplasmic reticulum and free ribosomes observed within the supranuclear regions of the principal cells of the African sideneck turtle are features of a protein synthesising cell. These are in conformity with previous reports on the principal cells of the epididymis in dogs and goats (Robaire and Hermo, 1988, Goyal and Williams, 1991; Schimming and Vicentini, 2008; Schimming et al., 2012).

The presence of tight junctions in the apical aspects of the epididymal epithelium of the African sideneck turtle is similar to earlier reports in reptiles by Sever, 2009 and Rheubert et al., $2010 \mathrm{~b}$ where the role of the formation of a blood-epididymis barrier was ascribed to them. The same has also been reported for principal cells in mammalian epididymis (Robaire et al., 2006; Cornwall, 2009). Tight junctions seal the apical aspects of the epithelium but do not occur basally, which may allow transport of materials externally through intercellular canaliculi (Rheubert et al., 2010b). In this study, small vesicles were observed along the canaliculi as well as the basal membrane. The dilated intra-cytoplasmic spaces between cells 


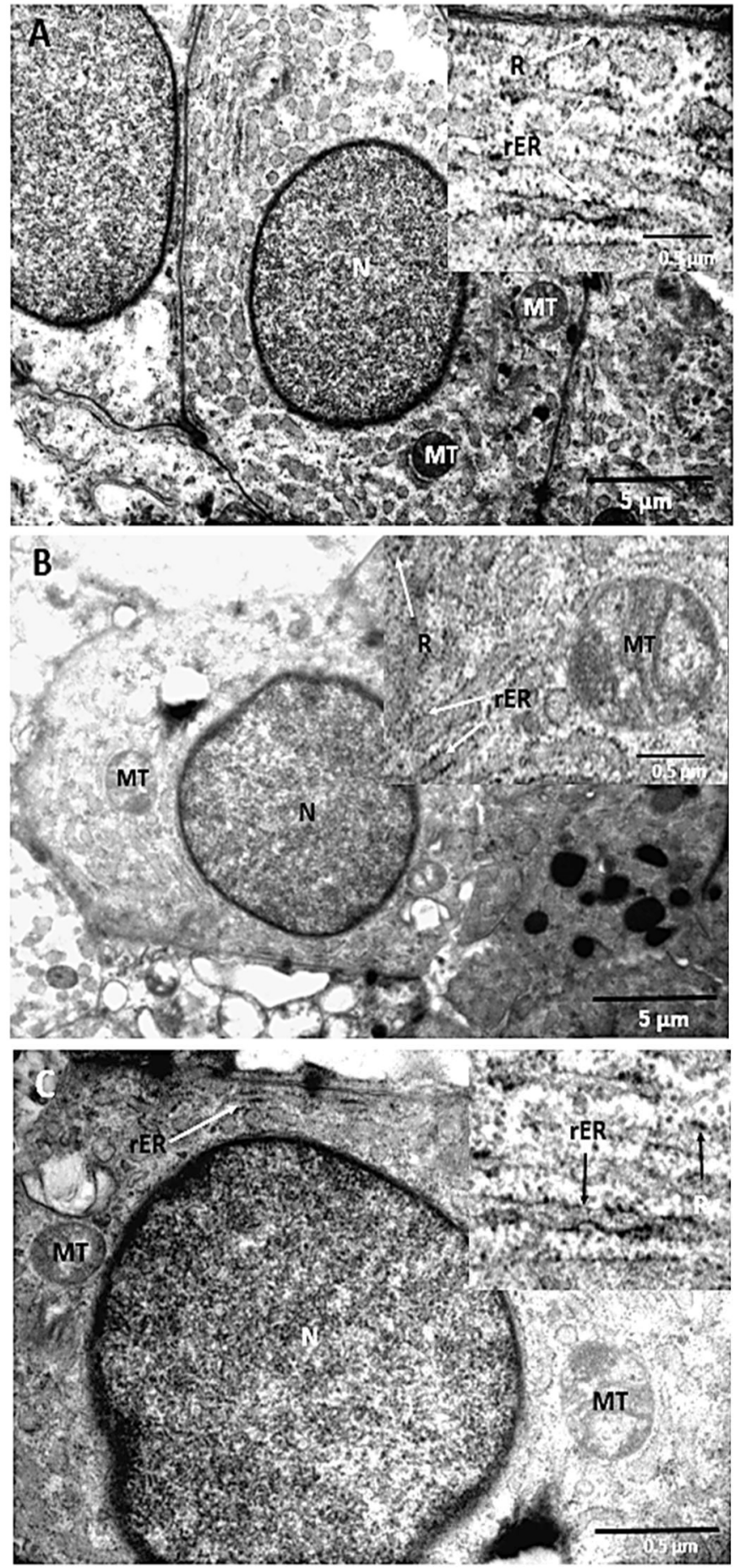

Fig. 6: Transmission Electron Micrograph of the intraepithelial lymphocyte of the epididymis of the African sideneck turtle. (A) Proximal segment. N: nucleus of lymphocyte cell; MT: mitochondria. Inset: Cytoplasm of lymphocyte. R: free ribosomes; rER: rough endoplasmic reticula. (B) Middle segment. N: nucleus of lymphocyte cell; MT: mitochondria. Inset: Cytoplasm of lymphocyte. R: free ribosomes; rER: rough endoplasmic reticula; MT: mitochondria. (C) Posterior segment, $\mathrm{N}$ : nucleus of lymphocyte cell; MT: mitochondria. Inset: Cytoplasm of lymphocyte. R: free ribosomes; rER: rough endoplasmic reticula. are also suggestive of transport of water across epithelium (Hermo and Robaire, 2002)

The consistent position and structure of basal cells observed across the three segments of the epdididymis of the African sideneck turtle conforms with those of previous studies (Rheubert et al., 2010a; Schimming et al., 2012). Basal cells have been reported to be in close association with the overlying principal cells through the presence of cytoplasmatic extensions thereby forming an extensive cellular sheet surrounding the epididymal epithelium (Robaire et al., 2006; Cornwall, 2009). It has been suggested that basal cells may have a role within the processes of the epithelial immune system and in the regulation of electrolytes by principal cells (Cornwall, 2009).

The numerous mitochondria observed in the apical cells of the African sideneck turtle across the three segments of the epididymis are similar to those reported in the epididymis of the Geoffroy's side-necked turtle, Phrynops geoffroanus and the ground skink, Scincella lateralis (Cabral et al., 2011; Sever et al., 2013). Apical cells are clearly defined by the numerous mitochondria in the apical cytoplasm, the few microvilli at the luminal border and a nucleus that is located in the upper half of the cell cytoplasm (Adamali and Hermo, 1996; Robaire et al., 2006). Apical cells are related to sperm quiescence and to the regulation of the $\mathrm{pH}$ in the lumen through the production of enzymes of the carbonic anhydrase family (Hermo et al., 2005).

The intraepithelial lymphocytes reported to be found in the epididymis of $P$. castaneus in this study is at variance with the report of Rheubert et al. (2010a) in the Mediterranean Gecko even though intra-epithelial lymphocytes were reported for the rete testis of the same Mediterranean Gecko as resembling the "halo cells" of mammalian epididymis (Hermo and Robaire, 2002; Rheubert et al., 2010b). Intra-epithelial leukocytes have also been reported in the epididymis of lizards (Meeran et al., 2001). Hermo and Robaire (2002) described these leukocytes as either monocytes or T-lymphocytes. Intra-epithelial lymphocytes were also reported to be present in the epididymis of the African giant rat, Cricetomys gambianus, Waterhouse (Oke et al., 1987, 1989).

The posterior segment of the epididymis, like the cauda epididymis of mammals contained more spermatozoa than its proximal and middle portions. This is in conformity with previous reports on the epididymis of mammals (Oke and Aire, 1990; Massanyi et al., 2003; Olukole et al., 2009; Olukole and Obayemi, 2010) and reptiles (Sever, 2009, Rheubert et al., 2010b; Cabral et al., 2011; Sever et al., 2013). Ultrastructural observations of the epithelial lining cells of the posterior segment in the African sideneck turtle, suggest that the segment exerts other morphological roles than storage of spermatozoa. Active processes of uptake and release of substances among the cells and the luminal content has been proposed in mammals. It has been reported that the proteins and small molecules secreted by epithelium of the epididymis into the lumen interact with the transiting spermatozoa and directly or indirectly affect the spermatozoal surface and that these proteins alongside small molecules function as signaling molecules to induce activity in the other epididymal proteins (Gatti et al., 2004). Studies on mammalian epididymis had suggested that processes of cellular resorption of water, salt 
ions and macromolecules as well as protein secretion, sperm final maturation and storage of quiescent sperm occur in this segment (Flickinger, 1983; Arrighi et al., 1993).

The presence of clear cells in the posterior segment of the epididymis of the African sideneck turtle is similar to the report on the epididymis of the Geoffroy's side-necked turtle, Phrynops geoffroanus (Cabral et al., 2011) as well as the ground skink, Scincella lateralis (Sever et al., 2013). Clear cells have been reported as endocytic cells which may be responsible for the clearance of proteins from the epididymal lumen, taking up the contents of the cytoplasmic droplets released by the spermatozoa as they transit through the duct (Hermo et al., 2005; Robaire et al., 2006). It can however, be inferred from this study that the posterior segment secretes the least protein into the duct lumen.

\section{Conclusions}

In conclusion, the proximal, middle and posterior segments of the epididymis of the African sideneck turtle has been found to contain principal, basal, apical cells and intra-epithelial lymphocytes, each with specific micro-anatomical characteristics. Clear cells are found mainly in the posterior segment, suggestive of structural evidence of basic endocytotic function. The apical and principal cells show evidence of both secretory and absorptive functions while the basal cells and clear cells have been postulated to have a role in the processes of epithelial immune system.

\section{Acknowledgements}

Authors are grateful to Dr L. Du Plesis of the ElectronMicroscopy Unit, Department of Veterinary Anatomy and Physiology, Faculty of Veterinary Science, University of Pretoria, South Africa for the technical assistance rendered.

\section{Conflict of Interest}

The authors declare that there is no conflict of interest.

\section{Grants}

The authors are grateful to the University of Ibadan, Ibadan, Nigeria for Senate Research Grants (SRG/FVM/2010/4A and $\mathrm{SRG} / \mathrm{FVM} / 2010 / 1 \mathrm{~B})$ to BOO that aided this study.

\section{Author Contributions}

SGO and BOO designed, executed and jointly wrote the manuscript.

\section{References}

Adamali, H.I. and Hermo, L. (1996). Apical and narrow cells are distinct cell types differing in their structure, distribution, and functions in the adult rat epididymis. $J$. Androl., 17(3):208-222

Aire, T.A. (2007). Anatomy of the testis and male reproductive tract. In: Jamieson BGM, Ed. Reproductive biology and phylogeny of birds. NH: Science Publishers, Enfield, pp 37-113

Akbarsha, M.A., Tamilarasan, V. and Kadalmani, B. (2007). Light and electron microscopic observations of fabrication, release, and fate of biphasic secretion granules produced by epididymal epithelial principal cells of the fan-throated lizard Sitana ponticeriana cuvier. $J$. Morphol. 267:713-729

Arrighi, S., Romanello, M.G. and Domeneghini, C. (1993). Ultrastructure of epididymal epithelium in Equus caballus. Ann. Anat., 175:1-9

Broadley, D.G. and Boycott, R.C. (2009). Pelusios sinuatus (Smith 1838) -Serrated Hinged Terrapin. Conservation Biology of Freshwater Turtles and Tortoises. Chel. Res. Monogr., 5: 036.1-036.5

Cabral, S.R.P., Zieri, R., Franco-Belussi, L., Santos, L.R.S., Zago, C.E.S. and Taboga, S.R. (2011). Morphological changes of the epididymis and description of the excurrent ducts of Phrynops geoffroanus (Testudines: Chelidae) during the reproductive cycle. Anat. Rec., 294:145-155

Cornwall, G.A. (2009). New insights into epididymal biology and function. 400, New York, EUA. Hum. Reprod. Update., 15(2):213-227

Dacheux, J.L., Castella, S., Gatti, L.J. and Dacheux, F. (2005). Epididymal cell secretory activities and the role of the proteins in boar sperm epididymis. Theriogenol., 63(2):319-341

Djakiew, D. and Jones, R.C. (1982). Ultrastructure of the ductus epididymidis of the echidna, Tachyglossus aculeatus. $J$. Anat., 135:625-634

Flesch, F.M. and Gadella, B.M. (2000). Dynamics of the mammalian sperm plasm membrane in the process of fertilization. Biochimica et Biophysica Acta 1469(3):197235

Flickinger, C.J. (1983). Synthesis and secretion of glycoprotein by the epididymal epithelium. J. Androl., 4:157-161

Gatti, J.L., Castella, S., Dacheux, F., Ecroyd, H., Metayer, S., Thimon, V. and Dacheux, J.L. (2004). Post-testicular sperm environment and fertility. Anim Reprod Sci., 8283:321-339

Gist, D.H., Dawes, S.M., Terry, W., Turner, T.W., Sheldon, S. and Congdon, J.D. (2001). Sperm Storage in Turtles: A Male Perspective. Expt. Zool., 292:180-186

Goyal, H.O. and Williams, C.S. (1991). Regional differences in the morphology of the goat epididymis: a light microscopic and ultrastructural study. Am. J. Anat., 190:349-369

Hermo, L, Chong, D.L, Moffatt, P., W.S., Waheed, A. and Smith, C.E. (2005). Region and cell - specific differences in the distribution of carbonic anhydrases II, III, XII, and XIV in the adult rat epididymis. J. Histochem. Cytochem. 53(6):699-713

Hermo, L., Dworkin, J. and Oko, R. (1988). Role of epithelial clear cells of the rat epididymis in the disposal of the contents of cytoplasmic droplets detached from spermatozoa. Am J Anat., 183:107-124

Hermo, L., Papp, S. and Robaire, B. (1994). Developmental expression of the Yf subunit of glutathione S-transferase $\mathrm{P}$ in epithelial cells of the testis, efferent ducts, and epididymis of the rat. Anat. Rec., 239:421-440

Hermo, L. and Robaire, B. (2002). Epididymis cell types and their function. In The Epididymis: From Molecules to Clinical Practice (B. Robaire and B. T. Hinton, Eds.), Kluwer Academic/Plenum, New York, pp 81-102 
Holmes, H.J. and Gist, D.H. (2004). Excurrent duct system of the male turtle Crysemys picta. J. Morphol., 261(3):312322

Kellner, A. and Schwanke, C. (2001). Repteis fosseis do Brasil: breve introducao a herpetologia. In: Brito IM. (Ed.). Geologia historica, Uberlandia: Edufu, pp 303-363

Kirkpatrick, D.T. (1995). An Essay on Taxonomy and the Genus Pelusios. http://www.unc.edu/ dtkirkpa/stuff/pel. html. Accessed 22 February 2013.

Massanyi, P., Jancova, A. and Uhrin, V. (2003). Morphometric study of male reproductive organs in the rodent species Apodemus Sylvaticus and Apodemus flavicollis. Bull. Vet. Inst. Pulway., 47:133-138

Meeran, M.M., Daisy, P. and Akbarsha, M.A. (2001). Histological differentiation along the ductus epididymides of the lizard Calotes versicolor Daudin. $J$ Anim. Morphol. Physiol., 48:85-96

Oke, B.O., Aire, T.A., Adeyemo, O. and Heath, E. (1987). The structure of the epididymis of the African the giant rat (Cricetomys gambianus, Waterhouse). Histochemical and microstereological studies. J. Anat., 160:9-19

Oke. B.O., Aire, T.A., Adeyemo, O., Heath, E. (1989). The ultrastructure of the epididymis of the African giant rat (Cricetomys gambianus, Waterhouse). J Anat., 165:75-89

Oke, B.O. and Aire, T.A. (1990). Ultrastructural evidence for secretion in different zones of the caput epididymis of the African giant rat (Cricetomys gambianus, Waterhouse). Arch. Vet. Med., 60 (4):207-212

Olukole, S.G., Oyeyemi, M.O. and Oke, B.O. (2009). Biometrical observations on the testes and epididymis of the domesticated adult African great cane rat (Thryonomys swinderianus). Eur. J. Anat., 13(2):71-75

Olukole, S.G. and Obayemi, T.E. (2010). Histomorphometry of the Testis and Epididymis in the domesticated adult African great cane rat (Thryonomys swinderianus). Int. J. Morphol., 28(4):1251-1254

Olukole, S.G. and Oke, B.O. (2014). Morphological analysis of the plastron of the African sideneck turtle (Pelusios castaneus) Trop. Vet., 32(1\&2):26-35

Olukole, S.G., Oyeyemi, M.O. a nd Oke, B.O. (2014a). Biometrical and histometrical observations on the testis and epididymis of the African sideneck turtle (Pelusios castaneus). Eur. J. Anat., 18 (2):102-108

Olukole, S.G., Oyeyemi, M.O. a nd Oke, B.O. (2014b). Spermatogenic cycle of the African sideneck turtle, Pelusios castaneus (Schweigger, 1812) (Reptilia: Testudines), Ital. J. Zool., 81(1): 25-31 .

Olukole, S.G., Madekurozwa, M-C. and Oke, B.O. (2018). Spermiogenesis in the African sideneck turtle (Pelusios castaneus): Acrosomal vesicle formation and nuclear morphogenesis. J. King Saud Univ. - Science 30: 359-366

Rao, R.J.and Shaad, F.U. (1985). Sexual cycle of the male freshwater turtle, Trionyx gangeticus (Cuvier) Herpetologica 41(4):433-437
Rheubert, J.L., Wilson, B.S., Wolf, K.W. and Gribbins, K.M. (2010a). Ultrastructural study of spermiogenesis in the Jamaican Gray Anole, Anolis lineatopus (Reptilia: Polychrotidae). Acta. Zool (Stockholm)., 91:484-494

Rheubert, J.L., McMahan, C.D., Sever. D.M., Bundy. M.R., Siegel, D.S. and Gribbins, K.M. (2010b). Ultrastructure of the reproductive system of the Black Swamp Snake (Seminatrix pygaea). VII. Spermatozoon morphology and evolutionary trends of sperm characters in snakes. J. Syst. Zool. Evol.. Res., 48:366-375

Robaire, B. and Hermo, L. (1988). Efferent ducts, epididymis and vas deferens: structure, functions and their regulation. In: The physiology of reproduction, Knobil and J. Neil, (Ed.), Raven Press, New York, pp 999-1080

Robaire, B., Hinton, B.T. and Orgebin-Crist, M.C. (2006). The Epididymis. In: The physiology of reproduction, Knobil and J. Neil, (Ed.), Elsevier, pp 1071-1148

Schimmimg, B.C., Pinheiro, P.F.F., Vicentini, C.A. and Domeniconi, R.F. (2012). Ultrastructure of the epithelium lining of cauda epididymidis in mongrel dogs. Pesq. Vet. Bras., 32(1):32-36

Schimming, B.C. and Vicentini, C.A. (2008). Morphological features of the apical region in the principal cells of mongrel dog epididymis. Int. J. Morphol., 26:149-153

Setchell, B.P., Sanchez-Partida, L.G. and Chairussyuhur, A. (1993). Epididymal constituents and related substances in the storage of spermatozoa: A review. Reprod. Fert. Devt. 5:601-612

Sever, D.M. (2009). Ultrastructure of the reproductive system of the black swamp snake (Seminatrix pygaea). Vi Anterior testicular ducts and their nomenclature. $J$. Morphol., 241:1-12

Sever, D.M., Rheubert, J.L., Hill, T.A. and Siegal, D.S. (2013). Observations on Variation in the Ultrastructure of the Proximal Testicular Ducts of the Ground Skink, Scincella lateralis (Reptilia: Squamata). J Morphol 274:429-446

Sullivan, R. (2004). Male fertility markers, myth or reality. Anim. Reprod. Sci., 82-83 341- 347

Wyneken, J. (2001). The Anatomy of Sea Turtles. U.S. Department of Commerce NOAA Technical Memorandum NMFS-SEFSC. 470, pp 1-172

Yanagimachi, R., Kamiguchi, Y., Mikamo, K., Suzuki, F. and Yanagimachi, H. (1985). Maturation of spermatozoa in the epididymis of the Chinese hamster. Amer. J. Anat., 172(4)317-330 